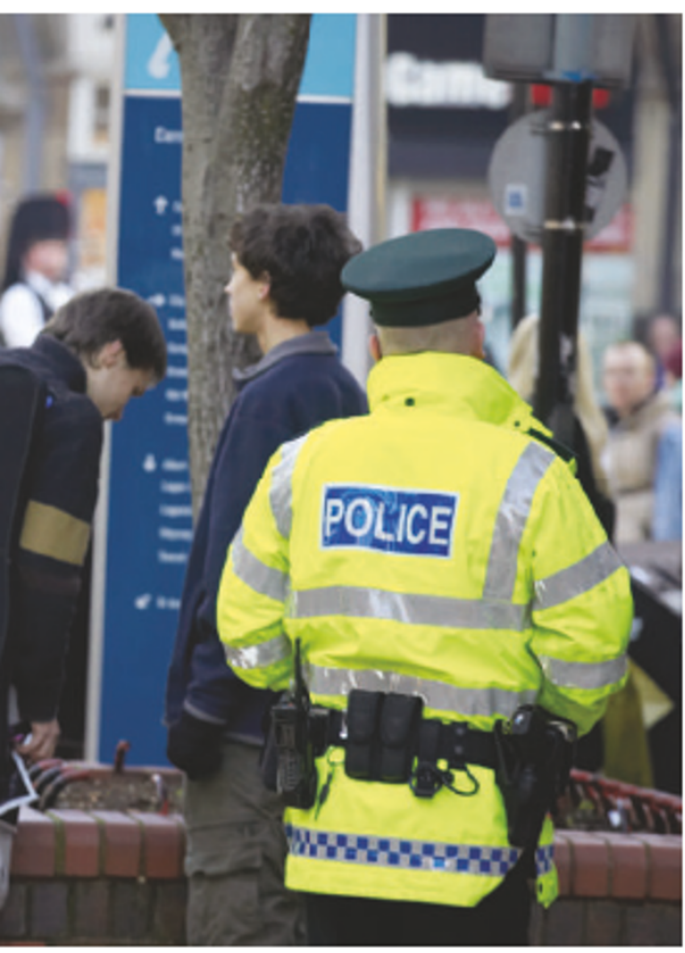

Selective evidence: data on crime initiatives were ignored by the UK Home Office.

science adviser, would be able to speak out if government science policy diverged sharply from the evidence, whereas few would expect such independence of US presidential science adviser John Marburger. But during King's six years in office, government policy and scientific thinking on high-profile issues such as climate change have not diverged substantially. An interesting test of his independence, and the government's commitment to evidence-based policy, will occur when they do. Jim Giles

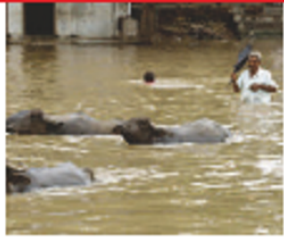

INDIA'S MONSOONS CAUSEMORE FLOODING Rains hit ting in the wrong place and time bring disaster.

www.nature.com/news

\title{
German stem-cell law under fire
}

Germany's strict laws governing human embryonic stem (ES) cells are no longer appropriate and need to be relaxed, says the country's main funding agency, the DFG.

Backing its arguments with an 80 -page report released on 10 November, the DFG argues that its previous support for a cautious approach is no longer valid.

When the DFG speaks, politicians listen, and a parliamentary debate is now likely. But federal research minister Annette Schavan, a Christian Democrat, swiftly rejected any fundamental change to the rules, which forbid German researchers from working on human ES cell lines created after January 2002. The penalty for doing so, either in or outside Germany, is up to three years in prison.

The DFG calls for three changes to the law. First, that the cut-off date be removed to give researchers access to the newer, better stem-cell lines used in other countries. Second, that human ES cell lines be allowed to be imported for clinical as well as research purposes. And third, that the threat of punishment for German researchers working abroad be lifted.

Despite Schavan's rejection of the recommendations, there are splits on the issue for the first time in both her party and its sister party, the Christian Socialists, with some members calling for the cut-off date to be abolished. The Social Democrat coalition partner and the opposition Free Democrats are also split.

In previous statements in 1999 and
2001 , the DFG called for continuing public debate about the possible benefits and limitations of stem-cell research, and for further research into the potential of adult stem cells to provide an alternative source of cells capable of generating different types of tissue. Its current report acknowledges that the past five years of international research has not only cast doubt on the potential of adult stem cells, but has also made clinical applications of human ES cells foreseeable. German researchers are being left behind, the report says, and isolated further by a reluctance abroad to include German researchers on international stem-cell committees for fear they may be prosecuted at home.

The outcome of the debate is uncertain, but politicians are broadly supportive of is againstchanging Germany's rules.

.

